\title{
Optimal Trichoderma strains for control of stem canker of brassicas: molecular basis of biocontrol properties and azole resistance
}

\author{
Adam Dawidziuk • Delfina Popiel • \\ Joanna Kaczmarek • Judyta Strakowska • \\ Malgorzata Jedryczka
}

Received: 21 May 2016/Accepted: 23 May 2016/Published online: 3 June 2016

(C) The Author(s) 2016. This article is published with open access at Springerlink.com

\begin{abstract}
Genus Trichoderma contains the most powerful agents used in biocontrol. Our study demonstrated that T. harzianum, T. hamatum and T. longibrachiatum can effectively control phytopathogenic fungi Leptosphaeria maculans and L. biglobosa. The effects of Trichoderma on pathogens' growth (in dual cultures on agar media) and on disease severity (on seedlings in controlled conditions) were also confirmed by field experiments. Additionally, spraying with conidiospores in the autumn was helpful in reducing the incidence and severity of phoma leaf spots. It has also accelerated the degradation of plant stubble and the decomposition of pathogens' fruiting bodies. Furthermore, all Trichoderma isolates showed higher cellulolytic activity and enhanced resistance to flusilazole treatments as compared to Leptosphaeria spp., which coincided with upregulation of $14 \alpha$-sterol demethylases and an AbcG5 transporter. The effects we observed justify the use of Trichoderma to enhance the resistance of oilseed rape against pathogens, which in turn may lead to a decrease in the use of pesticides.
\end{abstract}

Authors Adam Dawidziuk and Delfina Popiel are to be regarded as two first authors with equal contribution.

Handling Editor: Fouad Daayf

A. Dawidziuk · D. Popiel · J. Kaczmarek ·

J. Strakowska $\cdot$ M. Jedryczka $(\bowtie)$

Institute of Plant Genetics, Polish Academy of Sciences,

34 Strzeszynska, 60-479 Poznan, Poland

e-mail: mjed@igr.poznan.pl
Keywords $14 \alpha$-sterol demethylase $\cdot$ Azole transporter $\cdot$ Cellulolytic activity $\cdot$ Fungicide resistance $\cdot$ Oilseed rape

\section{Introduction}

Oilseed rape (Brassica napus L.) is one of the fastest expanding crops worldwide, with the European Union currently producing the highest amount of oilseed rape seeds and oil (http://faostat.fao.org). The great increase of oilseed rape production and its common use in crop rotations necessitates the introduction of new agronomic systems and of solving numerous problems related to crop protection against various pests, including weeds, insects and pathogens. The most damaging pathogens of oilseed rape are fungi. The incidence and severity of fungal species depend on field geographic location.

Leptosphaeria maculans (Desm.) Ces. et de Not is one of the most damaging pathogens to oilseed rape production worldwide. It is responsible for phoma leaf spotting and stem canker, also termed blackleg. The fungus is highly polymorphic (Kaczmarek et al. 2014a) and is responsible for yield losses of economic significance in all areas of intensive rapeseed cultivation, including Europe, Australia and Canada (Khangura and Barbetti 2001; West et al. 2001). In some areas, especially in Central and Eastern Europe, this species is accompanied by L. biglobosa (Kaczmarek 
and Jedryczka 2011; Piliponyte-Dzikiene et al. 2014). The latter pathogen is often associated with less damaging upper stem lesions (Fitt et al. 2006). However severe plant infections with L. biglobosa can also lead to substantial yield losses (Jedryczka 2007). Most of these diseases can be controlled using chemical treatments. However, the current EU policy of integrated pest management mandates a search for biological methods to combat these pathogens.

Antagonistic and hyperparasitic fungi have increasingly been used in integrated pest management technologies to reduce the amount of pesticides introduced into the environment (Chet 1987; Wachowska et al. 2013). Antagonists are naturally occurring organisms with traits enabling them to interfere with pathogen growth, survival, infection or plant colonization (Chernin and Chet 2002). Members of the genus Trichoderma are the most potent biocontrol agents (Druzhinina et al. 2011; Blaszczyk et al. 2014). The mechanisms underpinning the capacity of Trichoderma species to restrict plant pathogens include hyperparasitism. It is a complex process which can involve several events such as host recognition, direct attack as well as competition for nutrients and space (Roco and Perez 2001). This process also involves antibiosis, that is the production of secondary metabolites inhibiting the growth of other microorganisms without physical contact (Hjeljord and Tronsmo 1998; Bailey et al. 2008). Recent experiments have provided information to elucidating the mechanisms of antibiosis and disease suppressive activities of some Trichoderma species (Zhang et al. 2015). The fungi belonging to the genus Trichoderma produce over 180 secondary metabolites, including various toxins and antibiotics (Reino et al. 2008). Furthermore, Trichoderma produce extracellular cell wall degrading enzymes, including chitinases and $\beta$ 1,3-glucanases or peptaibols (Degenkolb et al. 2003). The mycolytic activity of these enzymes is considered to be a key factor in the hyperparasitic mechanism (Elad et al. 1982).

Many pathogens of crop plants can be successfully controlled by fungicides. Resistance of fungal strains to toxic compounds depends on the development of various mechanisms against these synthetic antifungal agents. These mechanisms relate to qualitative factors such as the absence or presence of a sensitive target site, or to quantitative factors such as uptake, transport, storage and metabolism (Deising et al. 2008).

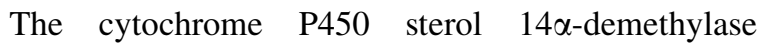
(CYP51) is an essential enzyme in the biosynthesis of sterols which are the components of cell membranes in eukaryotic organisms required for the regulation of membrane stability. Azole fungicides form the main class of antifungals used in agriculture and are known to target fungal sterol synthesis (Price et al. 2015). CYP51 mediated sterol biosynthesis is a target for the control of many fungal pathogens (Sheehan et al. 1999). The study of Becher et al. (2011) has shown that CYP51 is not a single gene, but there are two or more paralogues. Species with multiple copies of CYP51 can be resistant to some azoles. In fungi, drug transporters modulate the baseline sensitivity to fungicides, contribute to multidrug resistance (MDR) and virulence on host plants (de Waard et al. 2006). Two major groups of drug transporters that mediate membrane transport of foreign metabolites are the superfamilies of ATP-binding cassette (ABC) and the major facilitator superfamily (MFS) transporter. The role of $\mathrm{ABC}$ and MFS transporters in the efflux of fungicides is well known among some filamentous fungi (Sorbo et al. 2000; de Waard et al. 2006; Kretschmer et al. 2009). However no studies have been conducted with respect to Trichoderma spp.

Kowalska and Remlein-Starosta (2011) demonstrated the potential of a commercial product containing T. asperellum to control some diseases of oilseed rape, including phoma stem canker. In our study the hypothesis that morphological and molecular properties of Trichoderma spp. can help in protection of oilseed rape against stem canker of brassicas was tested. The studies included laboratory experiments to evaluate growth rate under different conditions, bioassays in dual cultures and analysis of cellulolytic properties as well as three-year field experiments on decomposition of oilseed rape stubble, and the potential of sprays with the spores of Trichoderma spp. to decrease phoma leaf spotting. We have also examined the reaction of Trichoderma spp. to flusilazole, a representative azole fungicide commonly used against stem canker of oilseed rape. The analysis included the main molecular mechanisms of biosynthesis of sterols (CYP51). We compared the characteristics of several species of Trichoderma, including those obtained 
from oilseed rape, as well as ones isolated from soil and plants other than oilseed rape.

\section{Materials and methods}

Fungal isolates

Leptosphaeria maculans and L. biglobosa isolates (Table 1) used in the study were collected at three sites located in the region of Wielkopolska (central-west Poland) over three seasons (2004-2006). Trichoderma spp. (hereafter Trichoderma) strains were obtained from oilseed rape plants (Brassica napus), soil from a greenhouse experiment with oilseed rape plants grown on peat compost and from yellow lupine (Lupinus luteus). The identification of species was based on fungal morphology and in the case of Trichoderma confirmed by DNA sequencing of ITS and tef- $1 \alpha$ (Blaszczyk et al. 2014).

\section{Expression of CYP51A, CYP51B and AbcG5} genes

\section{Primer design}

Primers allowing the detection of homologs of genes coding for $14 \alpha$-sterol demethylases were designed for the purpose of this study (Table 2) on the basis of back translated codon alignments created from protein sequence alignments of homologous genes from NCBI/RefSeq and Ensembl/Fungi. To normalise gene expression calculations two housekeeping genes were used: $\beta$-tubulin and actin (Table 2 ). The propensity of primers for homodimer and heterodimer formation was assessed on the basis of nearest neighbour energy/

Table 1 The origin of fungi used in the experiment

\begin{tabular}{|c|c|c|c|c|c|c|}
\hline No. & Fungal species & $\begin{array}{l}\text { Isolate } \\
\text { symbol }\end{array}$ & $\begin{array}{l}\text { Plant organ/ } \\
\text { habitat }\end{array}$ & $\begin{array}{l}\text { Location (country, } \\
\text { site) }\end{array}$ & Year & $\begin{array}{l}\text { Pathogen collection/NCBI } \\
\text { accession no. }\end{array}$ \\
\hline \multicolumn{7}{|c|}{ Leptosphaeria species } \\
\hline 1 & \multirow[t]{5}{*}{ L. biglobosa } & LBC101 & Leaf & PL, Cerekwica & \multirow[t]{3}{*}{2004} & \multirow{10}{*}{$\begin{array}{l}\text { Collection of the molecular } \\
\text { plant pathology team, IPG } \\
\text { PAS, Poznan }\end{array}$} \\
\hline 2 & & LBC102 & \multirow[t]{2}{*}{ Mature stem } & \multirow[t]{2}{*}{ PL, Pawlowice } & & \\
\hline 3 & & LBC103 & & & & \\
\hline 4 & & LBC104 & \multirow[t]{2}{*}{ Stem debris } & PL, Cerekwica & 2005 & \\
\hline 5 & & LBC105 & & PL, Kroscina Mala & 2006 & \\
\hline 6 & \multirow[t]{5}{*}{ L. maculans } & LMC101 & \multirow[t]{2}{*}{ Leaf } & \multirow[t]{2}{*}{ PL, Cerekwica } & \multirow[t]{2}{*}{2004} & \\
\hline 7 & & LMC102 & & & & \\
\hline 8 & & LMC103 & Mature stem & & & \\
\hline 9 & & LMC104 & Leaf & \multirow[t]{2}{*}{ PL, Pawlowice } & 2005 & \\
\hline 10 & & LMC105 & Stem debris & & 2006 & \\
\hline \multicolumn{7}{|c|}{ Trichoderma species } \\
\hline 11 & \multirow[t]{3}{*}{ T. atroviride } & TA1 & \multirow[t]{3}{*}{ Soil } & PL, Poznan & 2008 & FJ710062 \\
\hline 12 & & TA2 & & PL, Poznan & 2008 & FJ710065 \\
\hline 13 & & TA3 & & PL, Poznan & 2008 & FJ710066 \\
\hline 14 & T. hamatum & TH7 & Lupinus luteus & UA, Bucza & 2005 & FJ710058 \\
\hline 15 & \multirow[t]{4}{*}{ T. harzianum } & $\mathrm{T} 1 \mathrm{~S}$ & \multirow[t]{6}{*}{ Brassica napus } & PL, Zielecin & 2006 & FJ710061 \\
\hline 16 & & T3B & & PL, Zielecin & 2006 & FJ710060 \\
\hline 17 & & T4B & & PL, Zielecin & 2006 & FJ710059 \\
\hline 18 & & $\mathrm{~T} 13$ & & PL, Zielecin & 2006 & FJ710063 \\
\hline 19 & T. koningii & TE2 & & PL, Lublin & 2006 & FJ710057 \\
\hline 20 & T. longibrachiatum & TLA1 & & PL, Poznan & 2008 & FJ710064 \\
\hline
\end{tabular}

$P L$ Poland, UA Ukraine 
Table 2 The sequences of the primers used for gene expression analyses

\begin{tabular}{llll}
\hline Gene targeted & Primer name & Sequences $\left(5^{\prime}-3^{\prime}\right)$ & Efficiency $(\%)$ \\
\hline Azole transporter $(A b c G 5)$ & rt_ABCG5_fB2 & TAC TGT GAA CAA CTC GAT GT & 101.8 \\
& rt_ABCG5_rB2 & GAT CTC TTG GAA CTT CAC & 100.9 \\
Cytochrome P450 51A & rt_CYP51A_fA2 & TTC ACC CCC ATC AAC TTC AT & GCT CCT TGA TAG TGT CCA T \\
& rt_CYP51A_rA2 & CCC TAC CTC ACA ACC GAA AA & 98.9 \\
Cytochrome P450 51B & rt_CYP51B_am_fA2 & CAG CCC ATC AAG TTG GCT AT & AGC GAA TCC GAC CAT GAA GA \\
B-tubulin (reference) & rt_CYP51B_am_rA2 & CAC CGT CGT TGA GCC CTA & \\
Actin (reference) & rtBtubTRICHOF2 & ATC GGT ATG GGT CAG AAG GA & 99.2 \\
& rt_act_All_am_fA1 & GTC ATC TTC TCA CGG TTG GA & \\
\hline
\end{tabular}

The measurement of the efficiency was calculated according to the following equation: Efficiency $=-1+10^{\left(-1 / s^{\circ} \text { epe }\right.}$

melting temperature calculations with IDT OligoAnalyzer.

\section{Efficiency of the PCR reaction}

In order to obtain accurate and reproducible results, PCR reactions should have efficiency close to $100 \%$. The efficiency of the PCR between 90 and $110 \%$ means doubling of the amplicon at each cycle. This corresponds to a slope of -3.1 to -3.6 in the $C_{t}$ vs. log-template amount standard curve. The measurement of the efficiency was calculated according to the following equation:

Efficiency $=-1+10^{(-1 / \text { slope })}$

\section{RNA isolation and gene expression analysis}

The protocols of PCR, sequencing and thermal cycling conditions followed the methodologies described by Dawidziuk et al. (2014) and Popiel et al. (2014). For the analysis of expression of $C Y P 51 A, C Y P 51 B$ and $A b c G 5$ genes, the isolates were incubated four days before the addition of fungicides ( $3 \mathrm{mg}^{-1}$ of flusilazole). Two days after chemical treatment mycelia were collected from the Czapek-Dox medium, excess medium was separated from mycelium using a vacuum pump and then each sample was weighed on laboratory scales (Sartorius AG, Göttingen, Germany). Total RNA was purified from frozen mycelium, using the
RNeasy Plant Mini Kit (Qiagen, Hilden, Germany) according to the manufacturers' protocol with an additional DNase digestion step. The quality of total RNA was estimated by Nanodrop (Thermo Scientific, Wilmington, DE, USA) and via Bioanalyzer (Bio-Rad, Hercules CA, USA). The RT-PCR reaction was conducted using the $\mathrm{SYBR}^{\circledR}$ Green Quantitative RT-qPCR Kit (Sigma-Aldrich, UK). The total reaction volume was $25 \mu \mathrm{l}$ : $12.5 \mu \mathrm{l} \mathrm{SYBR}$ Green Taq Ready Mix, $1 \mu \mathrm{l}$ RNA (<35 ng), $0.5 \mu \mathrm{l}$ of each primer $(10 \mu \mathrm{M}), 0.125 \mu \mathrm{l}$ reverse transcriptase and $5.125 \mu \mathrm{l}$ nuclease free water. Gene expression profiles were determined through quantitative real-time PCR using a CFX96 Touch $^{\text {TM }}$ Real-Time PCR Detection System (Bio-Rad, Hercules, CA). The reaction was carried out using the following protocol: initial denaturation $94{ }^{\circ} \mathrm{C}$ for $2 \mathrm{~min}$, followed by 40 cycles at $94^{\circ} \mathrm{C}$ for $15 \mathrm{~s}$, $61{ }^{\circ} \mathrm{C}$ for $1 \mathrm{~min}$. The test was performed on the delta $\mathrm{Ct}$ values from the second day after fungicide exposure. The melting curve analysis (from $70{ }^{\circ} \mathrm{C}$ to $95{ }^{\circ} \mathrm{C}$ ) confirmed the specificity of primer pairs. In the experiment, we used three biological and two technical replicates together with a template-free negative control in each analysis of target and control genes. As a control, we used mycelium samples cultivated on medium without the addition of a fungicide. Relative quantification of gene expression was done using the 2- $\Delta \Delta \mathrm{Ct}$ method (Bio-Rad, Hercules, CA). All data were normalised to actin and $\beta$-tubulin (Table 2) genes as internal 
controls (Real-Time PCR Application Guide, BioRad, Hercules CA).

Measurement of cellulolytic activity

Fungal isolates were cultured in induction medium. Mycelial pellets were removed by centrifugation (15 min at $12.000 \mathrm{~g}$ ) and enzyme activities were measured in the obtained supernatant. Total cellulase activity was determined using the Filter Paper Activity (FPA) assay (Ghose, 1987). Whatman No. 1 filter paper $(50 \mathrm{mg}, 1 \times 6 \mathrm{~cm}$ strip; Whatman International, UK) was incubated for $60 \mathrm{~min}$ in $1 \mathrm{ml}$ of $0.05 \mathrm{M}$ Na-citrate buffer solution $(\mathrm{pH} 4.8)$ at $50{ }^{\circ} \mathrm{C}$ with an addition of $0.5 \mathrm{ml}$ enzyme solution (supernatant). The reaction was stopped by adding $1 \mathrm{ml}$ of DNS (3,5-dinitrosalicylic acid), according to Eveleigh et al. (2009). The released sugars were monitored spectrophotometrically (UV-1800 Spectrophotometer, Shimadzu, Japan). A calibration curve was established with glucose (POCH, Poland). Final cellulase activity was expressed in Filter Paper Units (FPU, $\quad\left[\mu \mathrm{mol} \times \mathrm{ml}^{-1} \times \mathrm{min}^{-1}\right]$ ), defined as the amount of enzyme which forms $1 \mu \mathrm{mol}$ of glucose per minute under the assay conditions. All samples were analysed in triplicate. A control strain, T. reesei QM 9414, originating from the Czech Collection of Microorganisms at Masaryk University in Brno was used as a reference. This mutant strain, with high cellulolytic activity $\left(0.30 \mu \mathrm{mol} \times \mathrm{ml}^{-1} \times \mathrm{min}^{-1}\right)$ is used for industrial production of cellulases.

Bioassays in laboratory conditions

\section{Dual cultures}

The bioassay analysis was performed using $9 \mathrm{~cm}$ diameter Petri dishes containing $20 \mathrm{ml}$ of PDA medium. For each pathogen-Trichoderma pairing, $5 \mathrm{~mm}$ diameter disks of pathogen and Trichoderma colonies were placed opposite each other at a distance of $1 \mathrm{~cm}$ from the edge of the plate. To allow the initial development of Leptosphaeria spp., the disks with the mycelium of $L$. maculans were placed at first (due to the slowest growth of this pathogen), the disks of L. biglobosa were placed on the medium four days later (this pathogen grows $c a$. 2.0-2.6 times faster than L. maculans), and the disks with Trichoderma were placed on the opposite site three more days later. As a result, the co-cultivation of the fungus pair L. biglobosa-Trichoderma spp. was shifted by three days and for the pair of L. maculans and Trichoderma spp. this time difference was seven days. Each variant of this 'shifted co-cultivation' (pathogen $\times$ antagonist) was replicated three times. Control plates contained single cultures of all tested fungi. Samples were incubated at $25{ }^{\circ} \mathrm{C}$ in the dark. Antagonistic effects on pathogen isolates was evaluated using a modified scale ranging from 0 to +8 , where 0 means no inhibition and +8 indicates total inhibition of a pathogenic fungus by an antagonist (Popiel et al. 2008). Growth rate of each control culture was measured at daily intervals starting three days after inoculation.

\section{Growth rate of fungal isolates treated with flusilazole}

Fungal response to the flusilazole was analysed by measurement of surface area of the mycelium (Leptosphaeria biglobosa, L. maculans, T. atroviride, T. hamatum, T. harzianum, T. longibrachiatum and $T$. koningii). Morphological changes of the isolates were studied on PDA and Czapek-Dox media with additional flusilazole $\left(3 \mathrm{mg} \mathrm{l}^{-1}\right)$ in simulated day/night conditions at $25^{\circ} \mathrm{C}$. In the final test, each assay was performed with ten replicates. The surface area of the mycelium was calculated as the area of an ellipse, based on measuring of the length and the width of the mycelium.

\section{Decomposition of plant residues}

Ten fragments of stems (10 cm long, $10 \mathrm{~mm}$ thick) of oilseed rape (cv. Californium) were soaked with water for $24 \mathrm{~h}$, then drained and placed in plastic containers. Subsequently they were sprayed with $1 \times 10^{6}$ or $1 \times 10^{7}$ spores $\mathrm{ml}^{-1}$ of the particular isolate of Trichoderma, covered with the lid and kept at room temperature $\left( \pm 20^{\circ} \mathrm{C}\right)$. The decomposition of stubble was described at one week time intervals, using a 0-9 scale, where 0 was no difference as compared to control and 9 was a full decomposition of stubble. The effect of Trichoderma was assessed by subtracting the decomposition values of control plants from corresponding values obtained from the plants treated with spore suspension. At each time-point of the 
experiment the number of fungal fruiting bodies on the oilseed rape stubble was calculated.

\section{Seedling bioassay in controlled environment conditions}

Fungal spores were produced on V8-agar on $90 \mathrm{~mm}$ Petri plates incubated at $25{ }^{\circ} \mathrm{C}$. Spore concentrations were adjusted to $1 \times 10^{7}$ spores $\mathrm{ml}^{-1}$ for inoculation. Oilseed rape plants were grown in four rows of 12 seedlings in $28 \times 35 \mathrm{~cm}$ plastic trays on peat compost manufactured by Klassmann ( $\mathrm{pH}$ 5.5-6.5). Inoculations were made on 12-day old plants, as described by Stachowiak et al. (2006). To perform the inoculation, each half-cotyledon was punctured with a needle. Spore suspensions of plant pathogens (10 $\mu$ droplets) were deposited directly onto each plant wound. After the inoculation, trays were covered with plastic lids and put in the darkness for $48 \mathrm{~h}$ and then transferred into a growth chamber with alternating $12 \mathrm{~h}$ periods at $24{ }^{\circ} \mathrm{C}$ (light) $/ 16{ }^{\circ} \mathrm{C}$ (dark) at $70 \% \mathrm{RH}$. Disease symptoms were scored 14 and 21 days after inoculation using a 0-6 rating scale. Every variant was studied in three replicates. Plant material consisted of an open pollinated cultivar of winter oilseed rape cv. Californium (Monsanto, USA), cv. Brise (Deutsche Saatveredelung AG) and cv. Bosman (Plant Breeding Strzelce Ltd).

\section{Field experiments}

\section{Weather conditions during field experiments}

Basic meteorological data in the five month periods, from July (harvest of the previous crop) to November (start of the winter pause) showed considerable differences between the summer-autumn seasons over the three years of the study. The weather in 2010 was the wettest, yet warm. The rainfall in the period lasting from mid July until the end of September, which is the usual time of pseudothecia formation, reached $263.2 \mathrm{~mm}$, whereas in the other years it did not exceed $100 \mathrm{~mm} .2009$ was the hottest and driest year, the rainfall in the designated period was only $68.2 \mathrm{~mm}$. The 2008 season was intermediate, the rainfall was sufficient and not excessive $(98.8 \mathrm{~mm})$ and (with the exception of October) the mean monthly temperatures did not exceed respective means of the other experimental years.

\section{Decomposition of plant residues}

Field studies were conducted over three seasons (2008/2009-2010/2011) at the Field Station of IPG PAS, located in Cerekwica, Poland (N 52 $31^{\prime} 10.0^{\prime \prime} \mathrm{E}$ $\left.16^{\circ} 41^{\prime} 33.0^{\prime \prime}\right)$ on plots of oilseed rape cv. Californium (Monsanto). The standard size of an individual plot was $1.5 \times 2 \mathrm{~m}\left(3 \mathrm{~m}^{2}\right)$. The experiments were performed during the autumn seasons of 2008-2010. Standardised fragments of stubble $(10 \mathrm{~cm}, 10 \mathrm{~mm}$ thick) of oilseed rape were kept in the field after harvest, with a density of 60 fragments per plot of $3 \mathrm{~m}^{2}$. The stubble was sprayed with spore suspensions of five species of Trichoderma $\left(1 \times 10^{6}\right.$ spores or $1 \times 10^{7}$ spores per $\left.\mathrm{ml}\right)$ and then kept in natural conditions and under plastic tents $(1 \mathrm{~m}$ diameter). The number of viable fruiting bodies (pycnidia and pseudothecia) was evaluated at weekly intervals $(0,7,14$ and 21 days post inoculation). The assessment of pseudothecia was done based on the A-D developmental scheme, as proposed by CETIOM and used by Dawidziuk et al. (2012).

\section{Leaf treatment with conidiospores of Trichoderma spp.}

Seeds of the oilseed rape cultivar Californium (Monsanto) were sown on individual plots of $1.5 \times 2 \mathrm{~m}$ size, with a sowing density of 50 plants per $\mathrm{m}^{2}$, using $25 \mathrm{~cm}$ rows. Plants were subjected to natural infection with the ascospores of L. maculans and L. biglobosa released from infected stubble originating from the previous season. When the plants reached $\mathrm{BBCH}$ stage 16 they were sprayed with spore suspensions of the studied Trichoderma species $\left(1 \times 10^{6}\right.$ or $1 \times 10^{7}$ spores per $\mathrm{ml})$. Half of the plots were then covered with transparent foil tunnels for seven days to examine the effect of a raised temperature. Each variant (year of experiment $\times$ Trichoderma species $\times$ spore density $\times$ temperature) was carried out with three replicates, measuring 30 leaf spots per replicate (width $\times$ length).

\section{Statistical analysis}

Statistical analyses comprised analyses of variance (ANOVA) and post-hoc means comparisons (TukeyKramer honestly significant difference [HSD]; $p \leq 0.05$ ) performed with the Statistica 9.0 software package (Stat Soft, USA). The differences in gene 
expression between non-treated and treated samples were analysed with Wilcoxon signed-ranks non-parametric tests $(p \leq 0.05)$ with the use of a one-tailed hypothesis. In RT-PCR reactions, the test was performed on the delta $\mathrm{Ct}$ values from the second day after fungicide exposure.

\section{Results}

Molecular identification of Trichoderma species

Based on the sequences of ITS1-5.8S rDNA-ITS2 region, ten Trichoderma isolates were ascribed to five species: T. harzianum Rifai (4 isolates), T. atroviride P. Karst (3), T. hamatum (Bonord.) Bainier (1), T. koningii Oudem (1) and T. longibrachiatum Rifai (1). All strains originating from plants of oilseed rape belonged to one of the three species: T. harzianum, $T$. koningii and $T$. longibrachiatum. The strains isolated from soil were identified as $T$. atroviride and the isolate obtained from yellow lupin belonged to $T$. hamatum. The sequences of the isolates were deposited in the NCBI Database (Table 1).

Growth rate of isolates

All Trichoderma species formed fast expanding colonies. The highest growth rate $\left(29 \mathrm{~mm} \mathrm{day}^{-1}\right)$ was observed for T. atroviride and T. longibrachiatum. The growth rate of $T$. hamatum and T. harzianum $\left(27 \mathrm{~mm} \mathrm{day}^{-1}\right.$ ) was followed by $T$. koningii $\left(23 \mathrm{~mm} \mathrm{day}^{-1}\right)$. The plant pathogens tested were among the slowest growing strains with growth rates of $3 \mathrm{~mm} \mathrm{day}{ }^{-1}$ for L. biglobosa and $1 \mathrm{~mm} \mathrm{day}^{-1}$ for L. maculans (Table 3).

Dual culture bioassays

The growth of the pathogenic isolates in dual cultures with competitive Trichoderma species was significantly reduced in all tested combinations except $L$. maculans co-inoculated with $T$. longibrachiatum. The isolates of $T$. atroviride caused growth inhibition of all tested fungal strains whereas T. hamatum, T. harzianum and T. koningii were more efficient in the assays with the isolates of L. biglobosa. In the case of dual culture of T. harzianum and T. longibrachiatum with L. maculans an inhibition zone between the pathogen and the antagonist was observed, which suggests the existence of antibiosis (Table 3).

Seedling bioassay in controlled environment conditions

Protective abilities of antagonistic fungi against pathogenic Leptosphaeria isolates were examined with cotyledon tests. In the first experiment, young oilseed rape plants were co-inoculated simultaneously with the antagonistic fungi alongside the phytopathogens. The co-inoculation of $L$. maculans with $T$. harzianum and with $T$. atroviride resulted in decreased disease severity on cv. Brise (Fig. 1a). A similar effect was observed on cv. Californium co-inoculated with L. maculans and T. longibrachiatum. The effect of decreased symptom severity was also found for co-inoculation of $L$. biglobosa with $T$. atroviride and with $T$. hamatum on both oilseed rape varieties.

Three weeks after the treatment of oilseed rape seedlings with Trichoderma isolates, followed by inoculation with the pathogens $L$. maculans and $L$. biglobosa, the protective abilities of all tested Trichoderma species were observed, with the exception of $T$. hamatum (Fig. 1b). A decrease of disease symptoms occurred in seven out of 24 co-inoculation combinations. In most cases it was one score point less in the evaluation scale, compared to inoculation with conidia of the pathogen only. The highest inhibition of pathogen activity was observed in 'shifted' co-cultivation with $T$. atroviride pre-treatment. The use of this species resulted in a decrease of the disease symptoms observed on cultivar Brise inoculated with $L$. $\mathrm{macu}$ lans and on cultivar Californium inoculated with $L$. biglobosa. No protective effect of Trichoderma was found on cv. Californium treated with L. maculans, but we have observed the activity of $T$. longibrachiatum, $T$. harzianum and $T$. atroviride against $L$. biglobosa (Fig. 1b).

Growth rate of fungal strains treated with flusilazole

Three species of Trichoderma were resistant to flusilazole treatment. The most resistant isolates of T. harzianum and T. longibrachiatum had their growth reduced by $10 \%$. In contrast the growth of $T$. hamatum was reduced by $40 \%$. Both the isolates of Leptosphaeria spp. and Trichoderma spp. were 
Table 3 The properties of Trichoderma isolates used in this study

\begin{tabular}{|c|c|c|c|c|c|}
\hline \multirow[t]{2}{*}{$\begin{array}{l}\text { Trichoderma } \\
\text { species }\end{array}$} & \multirow[t]{2}{*}{$\begin{array}{l}\text { Isolate } \\
\text { symbol }\end{array}$} & \multirow[t]{2}{*}{$\begin{array}{l}\text { Growth rate } \\
(\mathrm{mm} \pm \mathrm{SE})^{\mathrm{a}}\end{array}$} & \multirow[t]{2}{*}{$\begin{array}{l}\text { Cellulolytic activities (FPU per } \\
\min \pm \mathrm{SE})^{\mathrm{a}}\end{array}$} & \multicolumn{2}{|c|}{$\begin{array}{l}\text { Dual cultures } \\
\text { Trichoderma- } \\
\text { Leptosphaeria }\end{array}$} \\
\hline & & & & $\begin{array}{l}L . \\
\text { biglobosa }\end{array}$ & $\begin{array}{l}\text { L. } \\
\text { maculans }\end{array}$ \\
\hline \multirow[t]{3}{*}{ T. atroviride } & TA1 & $29.01 \pm 0.02 \mathrm{~d}$ & $0.20 \pm 0.017 \mathrm{abcd}$ & +6 & +6 \\
\hline & TA2 & $28.95 \pm 0.13 \mathrm{~d}$ & $0.17 \pm 0.006 \mathrm{ab}$ & +6 & +6 \\
\hline & TA3 & $29.04 \pm 0.18 \mathrm{~d}$ & $0.22 \pm 0.017 \mathrm{abcd}$ & +6 & +6 \\
\hline T. hamatum & TH7 & $27.07 \pm 0.06 \mathrm{bc}$ & $0.18 \pm 0.017 \mathrm{abc}$ & +6 & +5 \\
\hline \multirow[t]{4}{*}{ T. harzianum } & $\mathrm{T} 13$ & $26.83 \pm 0.19 b$ & $0.32 \pm 0.012$ ef & +5 & $+5^{\mathrm{c}}$ \\
\hline & T4B & $26.75 \pm 0.19 \mathrm{~b}$ & $0.28 \pm 0.057 \mathrm{cdef}$ & +6 & $+5^{\mathrm{c}}$ \\
\hline & $\mathrm{T} 3 \mathrm{~B}$ & $26.81 \pm 0.17 \mathrm{~b}$ & $0.37 \pm 0.029 \mathrm{f}$ & +6 & $+5^{\mathrm{c}}$ \\
\hline & $\mathrm{T} 1 \mathrm{~S}$ & $26.91 \pm 0.07 \mathrm{~b}$ & $0.21 \pm 0.050 \mathrm{abcd}$ & +6 & $+5^{\mathrm{c}}$ \\
\hline T. koningii & TE2 & $22.90 \pm 0.31 \mathrm{a}$ & $0.10 \pm 0.000 \mathrm{a}$ & +6 & +5 \\
\hline T. longibrachiatum & TLA1 & $29.00 \pm 0.16 \mathrm{~d}$ & $0.21 \pm 0.017 \mathrm{abcd}$ & +5 & $+3^{\mathrm{c}}$ \\
\hline T. reesei & QM 9414 & - & $0.30 \pm 0.046 \mathrm{def}$ & - & - \\
\hline
\end{tabular}

${ }^{a}$ Shared letters denote no statistical differences between Trichoderma isolates, with $p \leq 0.05$

b Scale range from 0 to +8 , where 0 means no inhibition and +8 indicates total inhibition of a pathogenic fungus

c $1 \mathrm{~mm}$ inhibition zone between the pathogen and the antagonist

- not studied
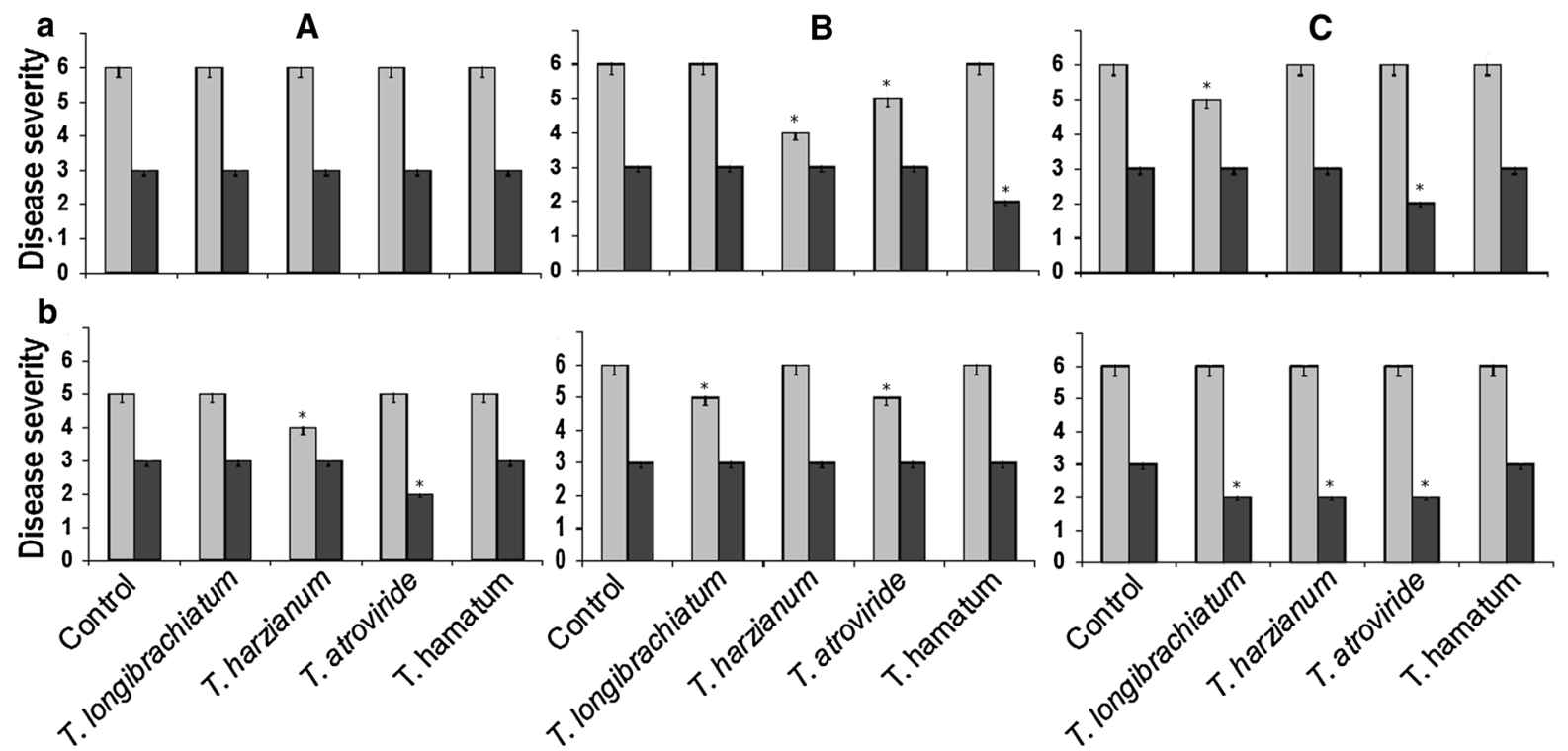

Fig. 1 Disease severity estimated: 14 days (a) and 21 days (b) after co-inoculation of Leptosphaeria maculans (grey bars) or L. biglobosa (black bars) with different Trichoderma species. Disease severity tested on three cultivars of oilseed rape:
Bosman (A), Brise (B), and Californium $(C)$. Bars indicate SE. Asterisks (*) mark statistical differences at $p \leq 0.05$ as compared to control 
susceptible to flusilazole. However, the isolates of $T$. hamatum, T. harzianum and T. longibrachiatum were significantly more resistant to flusilazole than $T$. atroviride, T. koningii and both Leptosphaeria species.

Expression of sterol 14 $\alpha$-demethylase (CYP51A and CYP51B) in Trichoderma cultures treated with fungicides

As the growth rate of T. harzianum, T. hamatum and $T$. longibrachiatum was not reduced significantly in the presence of the flusilazole, the expression of sterol $14 \alpha$-demethylases was examined. All tested genes exhibited increased activity in the presence of flusilazole. The strongest reaction was observed in $T$. longibrachiatum in which the relative normalised expression of both sterol $14 \alpha$-demethylases was raised over two times (CYP51A-2.8 fold; CYP51B-2.5 fold) (Fig. 2a, b). The isolates of T. harzianum and $T$. hamatum have also exhibited up-regulated expression of both sterol demethylases, but the normalised expression did not exceed 2.5-fold increase. Increases in the expression of CYP51A and CYP51B genes were statistically significant at $p \leq 0.05$ in all tested samples except in the case of CYP51B gene in $T$. harzianum. The expression of each gene was normalised using two housekeeping genes: $\beta$-tubulin and actin (Table 2). For each primer set, efficiency values ranged between 97 and $102 \%$ (Table 2), which corresponds to highly reliable and reproducible results.

Expression of the azole transporter AbcG5 in fungal cultures treated with fungicides

Degenerate, pan-species specific primers allowed amplification of parts of the AbcG5 gene and its possible orthologues in T. harzianum, T. hamatum and T. longibrachiatum. The orthologues of the AbcG5 in T. harzianum, T. hamatum and T. longibrachiatum were significantly upregulated in the presence of flusilazole $(p \leq 0.05)$. The highest relative expression was found in $T$. longibrachiatum where the increase was 9.57-fold (Fig. 2c).

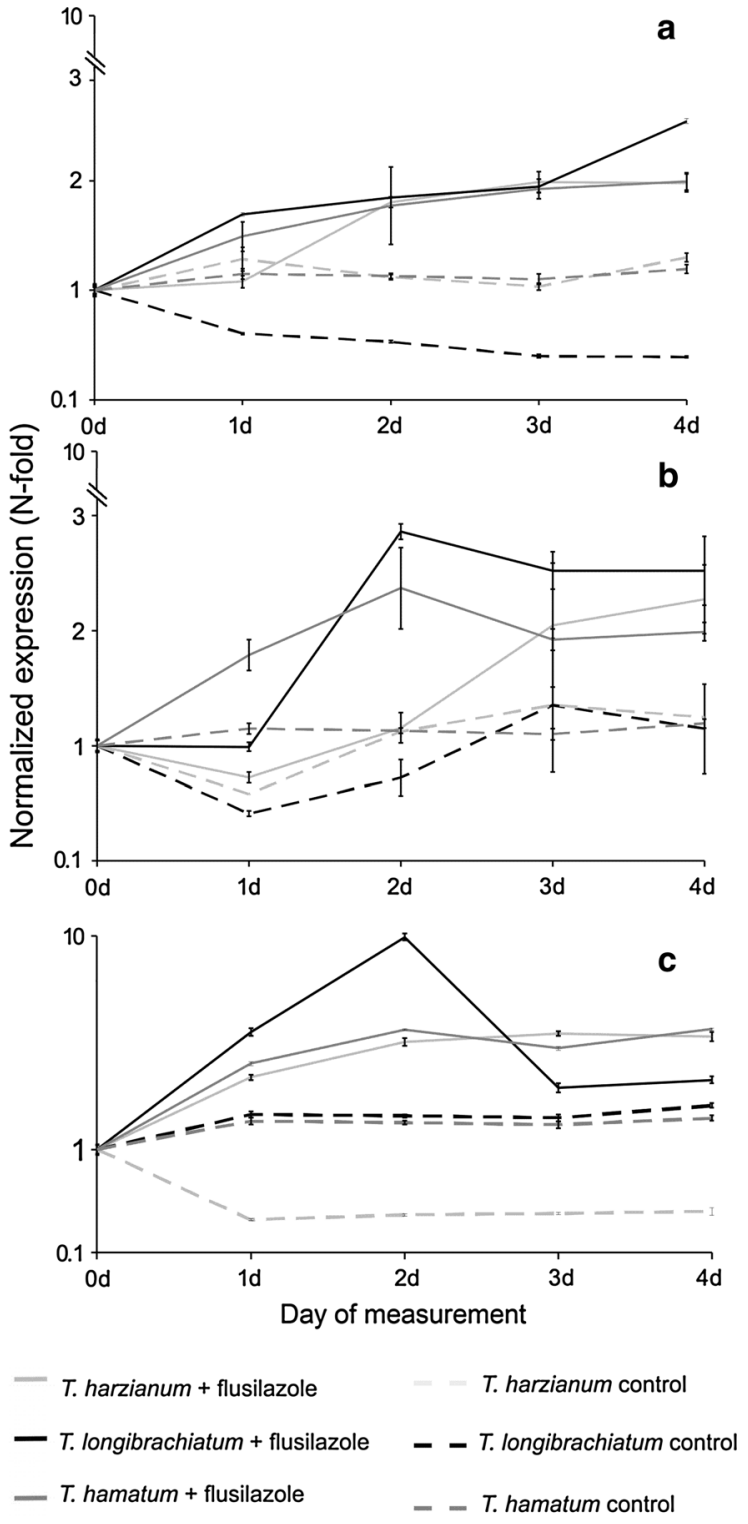

Fig. 2 Expression of CYP51A (a) CYP51B (b) and ABCG5 (c) genes in T. harzianum, T. longibrachiatum and T. hamatum isolates after flusilazole treatment. Bars indicate SE. Differences in gene expression were verified with Wilcoxon signedranks tests. One-tailed test performed on the second day after fungicide treatment (CYP51A-T. harzianum $(p=0.0128)$, T. longibrachiatum $(p=0.0139), T$. hamatum $(p=0.0178)$; CYP51B-T. harzianum $(p=0.1356), \quad$ T. longibrachiatum $(p=0.0029), T$. hamatum $(p=0.0027)$; ABCG5-T. harzianum $(p=0.0019), T$. longibrachiatum $(p=0.0011), T$. hamatum $(p=0.0012))$ 
Cellulolytic activity of Trichoderma strains

All tested isolates were able to degrade cellulose. However, the levels of decomposition efficiency measured by cellulase activity differed between isolates belonging to the same Trichoderma species and between the species. Among tested antagonistic strains, the highest specific cellulase activity (FPA) was observed for $T$. harzianum isolates (T3B$0.37 \mu \mathrm{mol} \times \mathrm{ml}^{-1} \times \mathrm{min}^{-1}$ and $\mathrm{T} 13-0.32 \mu \mathrm{mol} \times$ $\mathrm{ml}^{-1} \times \mathrm{min}^{-1}$ ) and it was higher than in the control isolate T. reesei $\mathrm{QM}$ 9414. The lowest value of cellulolytic activity was noted in $T$. koningii isolate TE2 $\left(0.1 \mu \mathrm{mol} \times \mathrm{ml}^{-1} \times \mathrm{min}^{-1}\right)$. The rest of examined isolates belonging to $T$. atroviride, T. hamatum and $T$. longibrachiatum demonstrated medium levels of cellulolytic activity (Table 3 ).

Decomposition of plant residues in laboratory conditions

The fragments of stems were gradually decomposed by the species of Trichoderma and the speed of stubble decomposition was related to the growth rate of the isolates: the slowest being $T$. koningii while the other four tested species were faster. There was a great reduction in the number of fruiting bodies of $L$. maculans $-L$. biglobosa species complex from 60 to 38 on average (reduction of $36.7 \%$ ) at one week after inoculation. Two weeks after inoculation, the average number of fruiting bodies still visible on stems was further reduced by half. At the same time the number of fruiting bodies on stubble treated with the Czapek-Dox liquid medium was also slightly reduced. This reduction was only $13.4 \%$ as compared to the start of the experiment. One week later, the reduction of the fruiting bodies of untreated stubble was $26.8 \%$ but at the same time new pycnidia and the first pseudothecia (classes A-C) were formed on stems. The stubble of oilseed rape treated with different species of Trichoderma was nearly totally decomposed and only few pycnidia were still visible (3.3 pycnidia on average per stem fragment). The strongest effect was observed for T. harzianum, and the weakest for T. koningii.

Leaf treatment with conidiospores of Trichoderma spp.

The year of the experiment (weather conditions) and the density of spores in the suspension had a
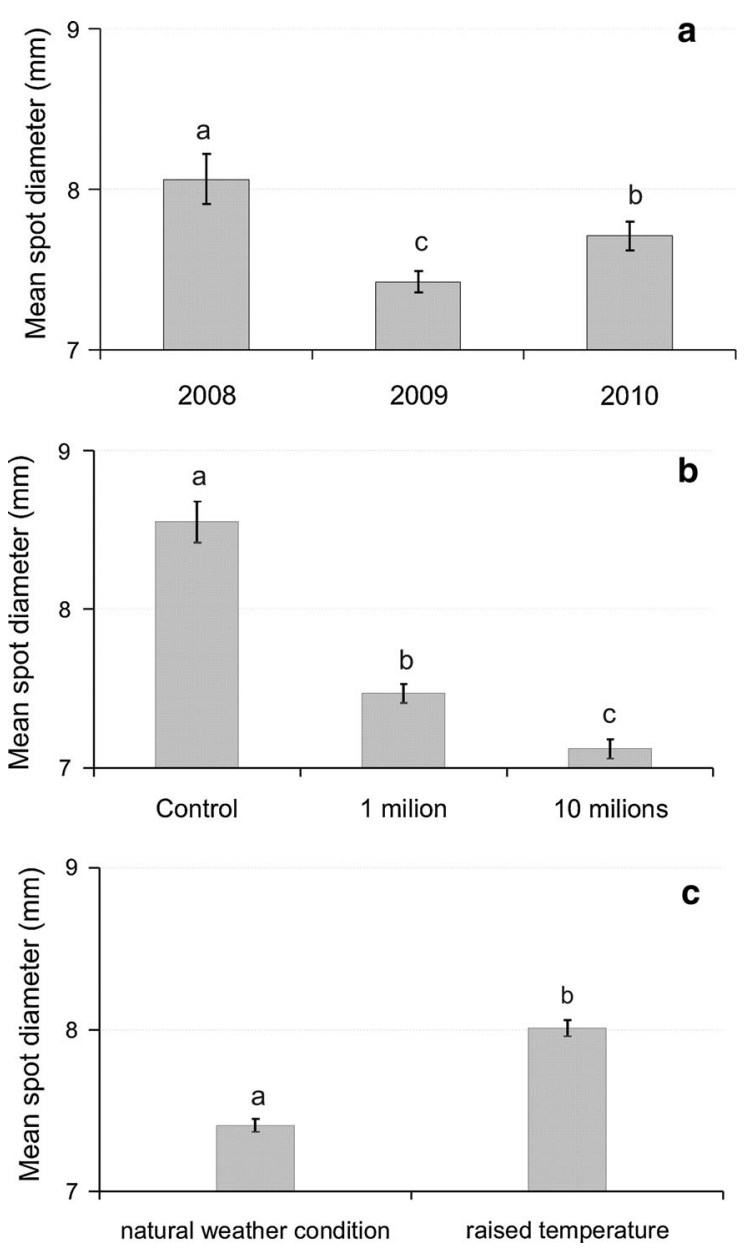

Fig. 3 Effect of leaf treatments with conidiospores of Trichoderma spp. in relation to: year (a), spore density (b), temperature (presence of the plant cover) (c). Shared letters in each panel denote no statistical differences at $p \leq 0.05\left(a: \mathrm{F}_{2,6477}=21.9\right.$, $p<0.001 ; b: \mathrm{F}_{2,6477}=141.95, p<0.001 ; c: \mathrm{F}_{1,6477}=65.36$, $p<0.001)$. Bars indicate SE

significant effect on the incidence and size of phoma leaf spots caused by L. maculans-L. biglobosa species complex (Fig. 3a, b). The most efficient were the sprays with $T$. harzianum and $T$. atroviride. Treatment of leaves by conidial suspension spray with any of Trichoderma species was ineffective in variants when the use of plastic covers raised temperatures (Fig. 3c).

\section{Discussion}

Our studies demonstrated that fungal species of the Trichoderma genus potentially can help to control stem canker of oilseed rape. The most effective was $T$. 
harzianum, which not only reduced the growth of oilseed rape pathogens in dual cultures, but also exhibited the inhibition zone, which is a typical symptom of antibiosis. This species was also most resistant to flusilazole - an active substance of azole fungicides. We have observed an increased expression of sterol 14 $\alpha$-demethylases and the AbcG5 azole transporter. In the seedling bioassays we observed that T. harzianum most effectively reduced symptoms of the disease, similarly to the results of dual culture tests. In some species desired traits were less consistently observed. For example, the results of the in vitro assays using $T$. longibrachiatum were discouraging, but the isolate of this species was the most resistant to an azole fungicide. In the presence of flusilazole the orthologues of the AbcG5 transporter in T. longibrachiatum were upregulated with the highest relative expression (nearly ten-fold). The isolates of $T$. atroviride were fast growing and caused growth inhibition of all tested fungal strains. However they were susceptible to the fungicide.

An additional advantage of Trichoderma species as a biocontrol measure is their resistance to azole fungicides (Khan and Shahzad 2007). This enables the simultaneous use of biological and chemical protection. Reduced amount of fungicides can weaken the pathogen and increase their susceptibility to attack by the resistant antagonist (Hjeljord and Tronsmo 1998). Degenerate, pan-species specific primers, designed by us for the purpose of this study, facilitated the amplification of parts of the $A b c G 5$ gene and its possible orthologues. Under our experimental conditions L. maculans and L. biglobosa were susceptible to flusilazole, which is one of the most common and efficient components of chemical treatments (Alert ${ }^{\circledR}$, Capitan ${ }^{\circledR}$ ) against phoma stem canker (Kaczmarek et al. 2014b). In our study the isolates of T. harzianum, $T$. hamatum and $T$. longibrachiatum were resistant towards this compound. Due to the common recognition of the main molecular mechanism of fungal resistance to the fungicide, the experiments we performed offered an explanation of this phenomenon at the molecular level. The reasons were sequence differences in sterol demethylase gene or upregulation of this gene. It is very likely that this additional quantitative resistance is a multidrug resistance (MDR). Literature data concluded that azole resistance was conditioned by changes in gene CYP51A, whereas $C Y P 51 B$ gene was associated primarily with the production of ascospores, and CYP51C, found only in fungi of the Fusarium genus, was associated with the virulence of strains (Fan et al. 2013). In our experiments we observed significant increases in the expression of CYP51A and CYP51B genes. Sequence differences at the CYP51A loci may explain differences in flusilazole resistance between the Trichoderma isolates. Additionally, the exposure to flusilazole treatment led to increased expression of AbcG5 gene in all resistant Trichoderma isolates. Based on the Ensembl Fungi programme (Kersey et al. 2010), the orthologue of this gene is a potential azole $\mathrm{ABC}$ transporter (Dubey et al. 2014).

The reduction of the disease symptoms varied greatly between different cultivars of oilseed rape tested. Despite the fact there were no considerable differences of the resistance towards the pathogens, the most favourable results of Trichoderma biocontrol were obtained for the cultivar Brise and the smallest effect was observed in cv. Bosman. The solution of this problem might be the use of a mixture of antagonistic isolates, compensating for differences associated with cultivars, connected with the rate of their development in the autumn, plant morphology (especially the number, size and shape of leaves), genetic resistance to stem canker and other characteristics. The number of fruiting bodies on plant stubble treated with Trichoderma rapidly decreased, as the stubble decomposed. Natural decomposition of the stubble and fruiting bodies was also observed when the stubble was moistened with the Czapek-Dox liquid medium. The rate of this process was much slower than with Trichoderma. It was connected with the activity of numerous fungi present in the air, such as Cladosporium spp., Alternaria spp., Penicillium spp. and others.

Our observations are in accordance with the results of previous studies, showing that chemical treatments are not the only way to combat plant pathogens (Chet 1987). Another approach is to apply antagonistic organisms as biological control agents. In case of the diseases of apples, carrots and peas, caused by Rhizoctonia, Sclerotinia and Fusarium species, effective control agents belonged to the genus Trichoderma as well as Gliocladium (Hjeljord and Tronsmo 1998). Among them T. harzianum is considered to be one of the most important species in biocontrol (Blaszczyk et al. 2014). This organism is commonly used to prevent the development of several soil pathogenic 
fungi (Roco and Perez 2001). The first commercialised biocontrol product contained an isolate of T. harzianum. It was registered for greenhouse crops and vineyards to control grey mould caused by Botrytis cinerea (Elad 2000).

At present, a considerable number of biocontrol products are used against S. sclerotiorum (Hjeljord and Tronsmo 1998). Antagonists, such as Coniothyrium minitans are effective mycoparasitic fungi controlling white mould (Li et al. 2006). The process of antibiosis caused by Pseudomonas spp. inhibited the germination of $S$. sclerotiorum ascospores (Savchuk and Fernando 2004). Although much is known about biocontrol of other potential oilseed rape pathogens, there is no sufficient information about the influence of antagonistic fungi on Leptosphaeria spp. The only published studies related to Bacillus amyloliquefaciens (Danielsson et al. 2007) and $T$. asperellum (Kowalska and Remlein-Starosta 2011).

The most important element of biological protection against plant pathogens is the efficiency in field conditions. In our experiments, the spray with Trichoderma conidiospores caused a statistically significant decrease of the disease incidence and severity. Moreover, the treatment with Trichoderma accelerated the degradation of the stems of oilseed rape, which was explained by high cellulolytic activity of these strains. In some cases it was higher to a standard isolate of $T$. reesei, which is commercially used to produce cellulases (Blaszczyk et al. 2014). There was also a significant reduction of the number of fruiting bodies of L. maculans-L. biglobosa species complex, both pycnidia and pseudothecia. Therefore, although the treatment had a relatively weak impact on the disease symptoms, it caused significant reduction of the primary inoculum. The results are partially in agreement with the effect of $T$. asperellum introduced in a commercial product, Trifender WP, to control Botrytis cinerea, Alternaria spp. and Phoma lingam in oilseed rape (Kowalska and Remlein-Starosta 2011). In the study performed by these authors, the treatment was done in stages BBCH61 and BBCH67 and the protection effectively limited symptoms of oilseed rape diseases and prevented the reduction of seed yield.

The proper use of biocontrol, such as the application of an adequate mixture of antagonistic isolates, resistant to chemical treatments, combined with agrotechnical methods and supplemented with decision support systems, can eliminate the most harmful pesticides and, as such, it can help to reduce the pollution of the environment. Future research should concentrate on biocontrol agents which not only directly influence the development of the pathogen in plant tissues but are also capable of reducing primary inoculum.

Acknowledgments Research partially funded under the project: "Molecular mechanisms of multidrug resistance to synthetic fungicides in fungi of the Fusarium genus" UMO2011/03/D/NZ9/02061. The authors thank to the Czech Collection of Microorganisms at the Masaryk University in Brno for the mutant strain T. reesei QM 9414 with increased production of cellulases. The revision of the manuscript was done with great help of Dr. Magdalena Sadys from Rothamsted Research, UK and Dr. William Truman from the Institute of Plant Genetics of the Polish Academy of Sciences, Poland.

Open Access This article is distributed under the terms of the Creative Commons Attribution 4.0 International License (http:// creativecommons.org/licenses/by/4.0/), which permits unrestricted use, distribution, and reproduction in any medium, provided you give appropriate credit to the original author(s) and the source, provide a link to the Creative Commons license, and indicate if changes were made.

\section{References}

Bailey BA, Bae H, Strem MD, Crozier J, Thomas SE, Samuels GJ, Vinyard BT, Holmes KA (2008) Antibiosis, mycoparasitism, and colonization success for endophytic Trichoderma isolates with biological control potential in Theobroma cacao. Biol Control 46:24-35

Becher R, Weihmann F, Deising HB, Wirsel SG (2011) Development of a novel multiplex DNA microarray for Fusarium graminearum and analysis of azole fungicide responses. BMC Genom 12:52

Blaszczyk L, Siwulski M, Sobieralski K, Lisiecka J, Jedryczka M (2014) Trichoderma spp.--application and prospects for use in organic farming and industry. J Plant Prot Res 54:309-317

Chernin L, Chet I (2002) Microbial enzymes in biocontrol of plant pathogens and pests. In: Burns R, Dick R (eds) Enzymes in the environment: activity, ecology, and applications. Marcel Dekker Inc., New York, pp 171-225

Chet I (1987) Trichoderma-application, mode of action, and potential as biocontrol agent of soilborne plant pathogenic fungi. In: Chet I (ed) Innovative approaches to plant disease control. John Wiley and Sons, New York, pp 137-160

Danielsson J, Reva O, Meijer J (2007) Protection of oilseed rape (Brassica napus) toward fungal pathogens by strains of plant-associated Bacillus amyloliquefaciens. Microb Ecol 54:134-140

Dawidziuk A, Kaczmarek J, Jędryczka M (2012) The effect of winter weather conditions on the ability of Leptosphaeria maculans and L. biglobosa to release pseudothecia. Eur J Plant Pathol 134:329-343 
Dawidziuk A, Koczyk G, Popiel D, Kaczmarek J, Buśko M (2014) Molecular diagnostics on the toxigenic potential of Fusarium spp. plant pathogens. J Appl Microbiol 116:1607-1620

de Waard MA, Andrade AC, Hayashi K, Schoonbeek HJ, Stergiopoulos I, Zwiers LH (2006) Impact of fungal drug transporters on fungicide sensitivity, multidrug resistance and virulence. Pest Manag Sci 62:195-207

Degenkolb T, Berg A, Gams W, Schlegel B, Grafe U (2003) The occurrence of peptaibols and structurally related peptabiotics in fungi and their mass spectrometric identification via diagnostic fragment ions. J Pept Sci 9:666-678

Deising HB, Reimann S, Pascholati SF (2008) Mechanisms and significance of fungicide resistance. Braz $\mathrm{J}$ Microbiol 39:286-295

Druzhinina IS, Seidl-Seiboth V, Herrera-Estrella A, Horwitz BA, Kenerley CM, Monte E, Mukherjee PK, Zeilinger S, Grigoriev IV, Kubicek CP (2011) Trichoderma: the genomics of opportunistic success. Nat Rev Microbiol 9:749-759

Dubey MK, Funck Jensen D, Karlsson M (2014) An ATPbinding cassette pleiotropic drug transporter protein is required for xenobiotic tolerance and antagonism in the fungal biocontrol agent Clonostachys rosea. Mol Plant Microbe Inter 27:725-732

Elad Y (2000) Trichoderma harzianum T39 preparation for biocontrol of plant diseases-control of Botrytis cinerea, Sclerotinia sclerotiorum and Cladosporium fulvum. Biocontrol Sci Technol 10:499-507

Elad Y, Chet I, Henis Y (1982) Degradation of plant pathogenic fungi by Trichoderma harzianum. Can $\mathrm{J}$ Microbiol 28:719-725

Eveleigh DE, Mandels M, Andreotti R, Roche C (2009) Measurement of saccharifying cellulose. Biotechnol Biofuels 2:21

Fan J, Urban M, Parker JE, Brewer HC, Kelly SL, HammondKosack KE, Fraaije BA, Liu X, Cools HJ (2013) Characterization of the sterol $14 \alpha$-demethylases of Fusarium graminearum identifies a novel genus-specific CYP51 function. New Phytol 198:821-835

Fitt BDL, Brun H, Barbetti MJ, Rimmer SR (2006) World-wide importance of phoma stem canker (Leptosphaeria maculans and L. biglobosa) on oilseed rape (Brassica napus). Eur J Plant Pathol 114:3-15

Ghose TK (1987) Measurement of cellulase activities. Pure Appl Chem 59:257-268

Hjeljord L, Tronsmo A (1998) Trichoderma and Gliocladium in biological control: an overview. In: Harman GE, Kubicek CP (eds) Trichoderma and Gliocladium-enzymes, biological control and commercial applications. Taylor and Francis Ltd, London, Great Britain, pp 131-151

Jedryczka M (2007) Epidemiology and damage caused by stem canker of oilseed rape in Poland. Phytopath Polonica 45:73-75

Kaczmarek J, Jedryczka M (2011) Characterization of two coexisting pathogen populations of Leptosphaeria spp. the cause of stem canker of brassicas. Acta Agrobot 64:3-14

Kaczmarek J, Brachaczek J, Jedryczka M (2014a) The effect of fungicide spray time on the incidence of stem canker of brassicas and seed yield of winter oilseed rape in Pomerania. J Plant Dis Protect 121:58-63
Kaczmarek J, Latunde-Dada AO, Irzykowski W, Cools HJ, Stonard JF, Jedryczka M (2014b) Molecular screening for avirulence alleles AvrLm1 and AvrLm6 in airborne inoculum of Leptosphaeria maculans and winter oilseed rape (Brassica napus) plants from Poland and the UK. J Appl Genet 5:529-539

Kersey PJ, Lawson D, Birney E, Derwent PS, Haimel M, Herrero J, Keenan S, Kerhornou A, Koscielny G, Kähäri A, Kinsella RJ, Kulesha E, Maheswari U, Megy K, Nuhn M, Proctor G, Staines D, Valentin F, Vilella AJ, Yates A (2010) Ensembl genomes: extending ensembl across the taxonomic space. Nucleic Acids Res 38:D563-D569

Khan MO, Shahzad S (2007) Screening of Trichoderma species for tolerance to fungicides. Pak J Bot 39:945-951

Khangura RK, Barbetti M (2001) Prevalence of blackleg (Leptosphaeria maculans) on canola (Brassica napus) in Western Australia. Aust J Exp Agric 41:71-80

Kowalska J, Remlein-Starosta D (2011) Research of nonchemical methods of winter oilseed rape protection in Poland. J Res Appl Agric Eng 56:220-223

Kretschmer M, Leroch M, Mosbach A, Walker AS, Fillinger S, Mernke D, Schoonbeek HJ, Pradier JM, Leroux P, De Waard MA, Hahn M (2009) Fungicide-driven evolution and molecular basis of multidrug resistance in field populations of the grey mould fungus Botrytis cinerea. PLoS Pathog 5:e1000696

Li GQ, Huang HC, Miao HJ, Ericksson RS, Jiang DH, Xiao YN (2006) Biological control of sclerotinia diseases of rapeseed by aerial applications of the mycoparasite Coniothyrium minitans. Eur J Plant Pathol 114:345-355

Piliponyte-Dzikiene A, Kaczmarek J, Petraitiene E, Kasprzyk I, Brazauskiene I, Brazauskas G, Jedryczka M (2014) Microscopic and molecular detection of airborne ascospores of Leptosphaeria maculans and L. biglobosa in Lithuania and Poland. Zemdirbyste-Agric 101:303-312

Popiel D, Kwasna H, Chelkowski J, Stepien L, Laskowska M (2008) Impact of selected antagonistic fungi on Fusarium species-toxigenic cereal pathogens. Acta Mycol 43:29-40

Popiel D, Koczyk G, Dawidziuk A, Gromadzka K, Blaszczyk L, Chelkowski J (2014) Zearalenone lactonohydrolase activity in Hypocreales and its evolutionary relationships within the epoxide hydrolase subset of $\mathrm{a} / \mathrm{b}$-hydrolases. BMC Microbiol 14:82

Price CL, Parker JE, Warrilow AGS, Kelly DE, Kelly SL (2015) Azole fungicides-understanding resistance mechanisms in agricultural fungal pathogens. Pest Manag Sci 71:1054-1058

Reino JL, Guerrero RF, Hernandez-Galan R, Collado IG (2008) Secondary metabolites from species of the biocontrol agent Trichoderma. Phytochem Rev 7:89-123

Roco A, Perez LM (2001) In vitro biocontrol of Trichoderma harzianum on Alternaria alternata in the presence of growth regulators. Electron J Biotechnol 4:1-2

Savchuk S, Fernando WG (2004) Effect of timing of application and population dynamics on the degree of biological control of Sclerotinia sclerotiorum by bacterial antagonists. FEMS Microb Ecol 49:379-388

Sheehan DJ, Hitchcock CA, Sibley CM (1999) Current and emerging azole antifungal agents. Clin Microb Rev 12:40-79 
Sorbo G, Schoonbeek H, De Waard MA (2000) Fungal transporters involved in efflux of natural toxic compounds and fungicides. Fungal Genet Biol 30:1-15

Stachowiak A, Olechnowicz J, Jedryczka M, Rouxel T, Balesdent MH, Happstadius I, Gladders P, Latunde-Dada A, Evans N (2006) Frequency of avirulence alleles in field populations of Leptosphaeria maculans in Europe. Eur J Plant Pathol 114:67-75

Wachowska U, Irzykowski W, Jedryczka M, StasiulewiczPaluch AD, Glowacka K (2013) Biological control of winter wheat pathogens with the use of antagonistic Sphingomonas bacteria under greenhouse conditions. Biocontrol Sci Technol 23:1100-1122

West JS, Kharbanda PD, Barbetti MJ, Fitt BDL (2001) Epidemiology and management of Leptosphaeria maculans (phoma stem canker) on oilseed rape in Australia, Canada and Europe. Plant Pathol 50:10-27

Zhang X, Harvey PR, Stummer BE, Warren RA, Zhang G, Guo $\mathrm{K}$, Li J, Hetong Y (2015) Antibiosis functions during interactions of Trichoderma afroharzianum and Trichoderma gamsii with plant pathogenic Rhizoctonia and Pythium. Funct Integr Genomic 15:599-610

Adam Dawidziuk received a $\mathrm{PhD}$ at the Institute of Plant Genetics of the Polish Academy of Sciences (IPG PAS) in Poznan, on modelling of the life cycle of oilseed rape (OSR) pathogens. Currently he is working in the Department of Pathogen Genetics and Plant Resistance (DPG\&PR) on functional evolution of transmembrane transporters.
Delfina Popiel has completed her PhD at the Institute of Plant Genetics of the Polish Academy of Sciences. Her PhD dissertation concerned the biological role, biocontrol potential and genetic diversity of Trichoderma strains obtained from decaying wood. Her work as a post-doc at DPG\&PR concerns research on molecular mechanisms of fungicide resistance.

Joanna Kaczmarek received a $\mathrm{PhD}$ at IPG PAS on plantpathogen interactions between oilseed rape and fungi causing stem canker. Currently her work at DPG\&PR concentrates on quantitative detection of pathogens in air, soil and plant tissues.

Judyta Strakowska has completed her PhD at IPG PAS on biochemical characters and genetic diversity of Trichoderma strains. Part of her work was studies on enzymatic activities of fungi. She is currently employed as a post-doc at the Division of Biology and Protection of Agriculture and Forestry Systems, Department of Agriculture, the University of Naples, Italy.

Malgorzata Jedryczka is a full professor in agronomy (since 2013), the head of the DPG\&PR at IPG PAS. Her work concerns the identification and characterization of fungi and plant resistance to pathogens using classical and molecular tools. The main models in her work are fungal pathogens of OSR. She is involved in creating decision support systems in crop plants. 